\title{
Myth, Orality and the African Novel
}

\author{
Graham K. Riach
}

\begin{abstract}
African authors are often wary of the term 'magical realism', seeing in it a suggestion of belatedness in relation to Latin American literature and a lack of awareness that magical realism's defining features have always been present in African orature and writing. For example, Zakes Mda, in his 1997 Olive Schreiner Prize acceptance speech for his novel Ways of Dying, responded ambivalently to his work being called magical realist:
\end{abstract}

Some critics have called my work magic realism. They say it was influenced by Latin-Americans. But I must tell you that the Latin-Americans have nothing to do with my work.

First of all they did not invent the mode of magic realism. They merely popularized it. Secondly, I had been writing in this mode long before I heard of the Latin-Americans. But in [my play We Shall Sing for the Fatherland] the interaction between the living and the dead is presented in a matter-of-fact manner, in the mode of magic realism. In magic realism the supernatural is not presented as problematic, or as contradicting our laws of reason. It does not contradict empirical reality. ... It happens and is accepted by other characters and by the reader as an event.

I wrote in this manner from an early age because I am a product of a magical culture.... The unreal happens as part of reality. The supernatural is presented without judgment. ${ }^{\mathrm{I}}$

Mda shared these concerns with Ben Okri who, speaking four years earlier in I993, was uncompromising:

The difference is this: the Latin American writers - let's be quite honest are largely European Latin American writers. Their writing has, as it were, come through the journey of symbolism, surrealism, and then come right round to the reality of that particular place. That's very different from what I'm saying. ... I'm looking at the world in The Famished Road from the inside of the African world view, but without it being codified as such. This

' Zakes Mda, 'Acceptance Speech for the Oliver Schreiner Prize (1997)', English Academy Review, I4 (I997): 279-28I; 28I. 
is just the way the world is seen: the dead are not actually dead, the ancestors are still part of the living community and there are innumerable gradations of reality, and so on. It's quite simple and straightforward. I'm treating it naturally. It's a kind of realism, but a realism with many more dimensions. ${ }^{2}$

Both Okri and Mda object, on the one hand, to the idea implicit in the term 'magical realism' that there is an accepted distinction between the natural and the supernatural. Mda says that he is the 'product of a magical culture' in which the 'unreal happens as part of reality', and that his writing represents this reality. Okri, in a similar vein, describes The Famished Road as coming from 'inside of the African world view' in which 'the dead are not actually dead', and he notes that 'this is just the way the world is seen'. For both authors, the very term 'magical realism' parses reality in a way neither author recognises as universally valid. This is not their only objection. Both also resist the implication that their writing is derivative of Latin American examples. The comparison with Latin America for them implies, in Brenda Cooper's words, 'slavish imitation ... a denial ... of local knowledge and beliefs, language and rhetoric; it seems to perpetuate imperialist notions that nothing new, intellectually or spiritually, originated in Africa'. ${ }^{3}$ While these are justifiable concerns, both Mda and Okri perhaps underestimate their own capacity to alter the very parameters of magical realism. In doing so, they underplay what engaging with this term might contribute to a global process of epistemological decentring. Magical realism's freakish figures and logical extravagances draw attention to the naturalisation of 'capitalist realism' - Mark Fisher's term for a sense that no coherent alternative to capitalism can be imagined - not through diametrical opposition, but rather by rivalling its grotesque disfigurements and abnormalities and by showing their shared

\footnotetext{
2 Ben Okri, 'Ben Okri: Interview with Jean W. Ross', in Donna Olendorf (ed.), Contemporary Authors I38 (Detroit: Gale, I993), pp. 336-341; 337-338.

3 Brenda Cooper, Magical Realism in West African Fiction: Seeing with a Third Eye (London: Routledge, 1998), p. 37. Although it is not my primary concern here, it is important to remember that Latin American magical realism is itself influenced by African cultural practices, in what Pietro Deandrea calls a 'transatlantic feedback cycle'. His argument recognises the clear influence Latin American writing has had on West African magical realism, but refuses the idea of unidirectional influence, noting that 'the culture of the Americas, in turn, was historically affected by philosophies imported through the slave trade'. In other words, the magical realism that emerged in Latin America has drawn on - but is not reducible to - African cultural practices, and equally, African magical realism might be related to - but is not simply derivative of - Latin American examples. See Pietro Deandrea, Fertile Crossings: Metamorphoses of Genre in Anglophone West African Literature (Amsterdam: Rodopi, 2002), p. 35.
} 
irrational premises. ${ }^{4}$ The alternative ways of knowing that magical realism offers actively intervene in the epistemological paradigms of the West (and the non-West), and in so doing contribute to the cultural politics of postcolonialism more broadly, which, in Robert Young's words, 'seeks to change the way people think, the way they behave, to produce a more just and equitable relation between the different peoples of the world'.

There has been no shortage of African authors - Anglophone, Francophone, Arabophone, Lusophone and Afrophone - whose work has shaped the category of magical realism. In the Anglophone sphere, Ato Quayson identifies Ben Okri, Kojo Laing and Syl Cheney-Coker as the 'exemplars of magical realism in African literature', while also noting 'the many localized examples of magical realism' in Elechi Amadi, Wole Soyinka, Dambudzo Marechera, Yvonne Vera and Zakes Mda. ${ }^{6}$ We might add to this list authors such as André Brink and K. Sello Duiker, in whose writing magical realism appears in both localised and more pervasive ways. The most frequently discussed Francophone African authors are Sony Labou Tansi, Henri Lopes, Boubacar Boris Diop, Calixthe Beyala, Tahar ben Jelloun and Abdelkebir Khatibi. ${ }^{7}$ In the Arabophone sphere, Xavier Luffin points to Abū Ahmad's tracing of magical realist elements in the work of Najīb Maḩūzọ, Khayrī Shalabī, Jamāl al-Ghīțānī and Idwār al-Kharrāt, while Fadia Suyoufie focuses on Ghādah al-Sammān, and Luffin himself examines the work of Ahmad al-Malik and 'Abd al-'Azīz Baraka Sākin, among others. ${ }^{8}$ Among Lusophone African authors, the works of Mia Couto, Pepetela, Orlanda Amarílis, Luandino Vieira, Paulina Chiziane, Jose Eduardo Agualusa, Abdulai Sila and Ungulani Ba Ka Khosa have all been read in magical realist terms. In Afrophone languages, examples can be found in the works of Euphrese Kezilahabi, who writes in Swahili, O. K. Matsepe, whose novels are in Northern Sotho, and Ngũgĩ wa

4 Mark Fisher, Capitalist Realism: Is There No Alternative? (London: Zero Books, 2009).

5 Robert J. C. Young, Postcolonialism: A Very Short Introduction (New York and Oxford: Oxford University Press, 2003), p. 3.

6 Ato Quayson, 'Magical Realism and the African Novel', in F. Abiola Irele (ed.), The Cambridge Companion to the African Novel (Cambridge: Cambridge University Press, 2009), pp. I 59-I76; I65.

7 For a useful rejoinder to reading Tansi's work as magical realist, see Lydie Moudileno, 'Magical Realism: "Arme Miraculeuse" for the African Novel?', Research in African Literatures, 37. I (2006): 28-4I.

8 Abū Ahmad Hāmid, Al-Wāqi'ìyah Al-Sihrīyah Fī Al-Riwāyah Al-'arabìyah [Magical Realism in the Arabic Novel] (Cairo: Al-Majlis al-a'lā li-l-thaqāfah, 2009); Fadia Suyoufie, 'Magical Realism in Ghādah al-Sammān's “The Square Moon”', Journal of Arabic Literature, 40.2 (2009): I 82-207; Xavier Luffin, 'Sudanese Magical Realism: Another Kind of Resistance to the Colonial/Imperialist Power?', Interventions, 20.2 (2018): 243-253. 
Thiong'o, whose later novels were first written in Gĩkũyũ before being selftranslated into English. As this list suggests, a large number of African authors, writing from greatly different geographical positions, cultural backgrounds, linguistic frameworks and literary inheritances, have been read through the critical optic of magical realism.

However, rather than assuming a taxonomic model in which works fall under a stable category called 'magical realism', it is more productive to see each work, and each critical engagement with it, as altering the conceptual parameters of magical realism. If we understand the term 'magical realism' to be shaped by a heady mix of cultural influences - indigenous belief systems, orature, capitalism, German romanticism, primitivism, ethnography, European surrealism and Latin American experimentalism, among others - then there is no reason to consider this shaping process to be closed. When magical realism, as a global aesthetic phenomenon and critical discursive category, encountered African artworks, its very nature was changed. New texts will inevitably be understood in relation to existing heuristic categories, and this will likely inform their interpretation, but these texts will, in turn, modify or mould those categories. In John Frow's words, 'No speaking or writing or any other symbolically organised action takes place other than through the shaping of generic codes, where "shaping" means both "shaping by" and "shaping of": acts and structures work upon and modify each other'. ' Given this mutually shaping process, instances and attributions of magical realism must be understood as performative acts that occur in tension between bottom-up and top-down definitional processes. While the term 'magical realism' has certainly accreted considerable conceptual ballast, and so describing a text using this term is not a neutral act, reading texts as magical realist should entail a re-evaluation of that term. African magical realist texts and their analyses can themselves be thought of as forms of speech act, of the order 'this is magical realism', in which the deixis operates performatively. While recognising that such utterances take place in a context of power - not every speaking position holds equal credence - new texts nevertheless alter the parameters of magical realism, rather than succeeding or failing to conform to its example.

In the texts I analyse below, Ngũgĩ wa Thiong'o's Mũrogi wa Kagogo (Wizard of the Crow, 2004-2006/2006) and Mia Couto's Terra Sonâmbula (Sleepwalking Land, 1992/2006), two factors in particular should cause us to change our understanding of magical realism: firstly, they help us

\footnotetext{
9 John Frow, Genre (New York and London: Routledge, 2006), p. Io.
} 
rethink the relationship between rationality, realism and capitalist modernity; and secondly, they contest the idea that orality and magic necessarily imply authenticity and a default stance of resistance. To understand how these novels alter our understanding of magical realism, let us first examine some of the assumptions built into this critical concept. In criticism of African magical realism, and of magical realism more broadly, there is an underlying premise that societal conditions produce - or at least provide the apposite conditions for - the emergence of magical realism in texts. ${ }^{\text {IO }}$ In this schema, it is a modern, rational, scientific worldview - most often linked to capitalist modernity - that leads to the realist component, and it is indigenous belief systems that lie behind the fantastical and fabulational aspects of the text. ${ }^{\text {I }}$ One influential example of this split can be found in Brenda Cooper's Magical Realism in West African Fiction: Seeing with a Third Eye, in which magical realism 'arises out of particular societies postcolonial, unevenly developed places where old and new, modern and ancient, the scientific and the magical views of the world co-exist'. ${ }^{\text {I2 }}$ In her conception, 'the magical is defined as the fictional device of the supernatural, taken from any source that the writer chooses, syncretized with a developed realistic, historical perspective'. ${ }^{3}$ In a similar vein, Yogita Goyal, echoing Fredric Jameson's argument in his essay 'On Magic Realism in Film' (1986), proposes that '[t]he effect of mingling realism and fantasy is to register the coexistence of capitalist and pre-capitalist modes of production in the post-colony'. ${ }^{14}$ For Goyal, as for Cooper, the suggestion is that the capitalist mode of production lies behind the text's realist component, while the pre-capitalist mode is responsible for the magical elements. Most surprising in these models, however, is not that the fabulous and the fantastical are associated with pre- or non-capitalism, but rather that rationality is associated so readily with capitalist modernity and that realism is taken as its neutral vehicle.

Despite what these portrayals above might suggest, there is no shortage of fabulation, irrationality and magical thinking present in the operations

Iо In this critical framework, a determining relationship - at least in the last instance - is assumed between societal conditions and cultural forms, a position that, despite its problems, I engage with on its own terms.

I This holds true for at least what Christopher Warnes terms 'faith-based' magical realism. Christopher Warnes, Magical Realism and the Postcolonial Novel: Between Faith and Irreverence (Basingstoke: Palgrave Macmillan, 2009), p. I 28.

${ }^{12}$ Cooper, Magical Realism in West African Fiction, p. 2 I6. $\quad{ }^{13}$ Ibid., p. I6.

I4 Yogita Goyal, 'Romance and Realism', in Simon Gikandi (ed.), The Novel in Africa and the Caribbean Since I950 (New York and Oxford: Oxford University Press, 2016), pp. 30I-3I5; 3 I 2; Fredric Jameson, 'On Magic Realism in Film', Critical Inquiry, I 2.2 (I986): 30I-325. 
of capitalism, nor is there a lack of conjuring and illusion in realism. Magical realism is not so much the melding of rational and irrational worldviews as the syncretisation of two systems in which irrationality plays a significant part. A variant of this idea is articulated by Kole Omotoso in The Form of the African Novel: A Critical Essay, in which he describes magical realism - although he uses the term 'marvellous realism' - as evidencing 'the juxtaposition of the belief system of one archaic economic and social system side by side with the belief system of another economic and social system, this time capitalism'. ${ }^{15}$ What Omotoso makes clear, and what has been downplayed in later reprisals of this argument, is that both are systems of belief with an important irrational component. Irrationality is everywhere in the operations of capitalism: Thorstein Veblen pointed out at the end of the nineteenth century that, although the notion of the rational economic agent undergirds much modern economic theory, irrationality is, in fact, an important factor in economic processes. ${ }^{16}$ Charles P. Kindleberger notes in Manias, Panics, and Crashes: A History of Financial Crises that while '[e]conomic theory is based on the assumption that men are rational', a paradox emerges, as 'the rationality assumption that underlies economic theory does not appear to be consistent with ... manias', and as a result, 'the two views must be reconciled'. ${ }^{17}$ If, as Cooper argues, ' $[\mathrm{m}]$ agical realism strives, with greater or lesser success, to capture the paradox of the unity of opposites', we must recognise that at least one of these opposing poles - the internal logic of capitalism - is itself paradoxical. ${ }^{18}$ Other examples abound: stock markets run on faith and are easily 'spooked'; legendary investor Warren Buffet is known as the 'sage of Omaha' due to his powers of market divination; we are encouraged to accept - despite growing global inequality - that the invisible hand of the market will transform avarice into social good; and we must square the circle of encouraging perpetual growth in a context of finite planetary resources. It is a struggle, even within the parameters of a cost-benefit model, to miss that the environmental catastrophe caused by capitalism is a form of cost that makes a mockery of its financial benefits. Capitalist modernity can syncretise with magic in magical realist texts not because

is Kole Omotoso, The Form of the African Novel: A Critical Essay (Akure and Ibadan: Fagbamigbe, 1979), p. 26.

${ }^{16}$ Thorstein Veblen, 'Why Is Economics Not an Evolutionary Science?', The Quarterly Journal of Economics, I2.4 (I898): 373-397.

${ }^{17}$ Charles P. Kindleberger and Robert Aliber, Manias, Panics, and Crashes: A History of Financial Crises, 5th ed. (Basingstoke: Palgrave Macmillan, 2005), p. 33.

${ }^{18}$ Cooper, Magical Realism in West African Fiction, p. I. 
of their radical differences, but rather because their shared irrationality creates a coupling point between them. Magical realist texts not only relativise capitalism's logics, but also dissolve that logic's internal consistency.

The conceptual syncretism of capitalist and indigenous worldviews in African magical realist texts is doubled in those works' representational strategies, as they draw on written and oral forms and defamiliarise both in the process. On the one hand, this strategy insists on orality's place as part of a global modernity, rather than considering it as an adjunct or supplemental practice. On the other, it defamiliarises realism, reminding us of the deep strangeness and long-standing suspicion of its uncanny doublings. Taking first the question of orality, as magical realism - as an analytical category - gained popularity in the I980s and I990s, it encountered existing cultural traditions. As critics such as F. Abiola Irele, Olakunle George and Quayson have pointed out, in Africa this process often meant colliding with oral forms that included magical elements. However, these oral forms are not somehow temporally anterior to the modern world; Irele convincingly argues that an awareness of orality is crucial for understanding the contemporary lifeworlds of Africa, and so the artworks that emerge from them. ${ }^{\text {I9 }}$ Orality, for Irele, is important not only for understanding ritual practices in Africa, but also for understanding day-today interactions, the ways in which oral forms such as proverbs structure thought and why African written works have the forms they do. This last concern is picked up and extended by George in his theorisation of the 'orality-literacy dyad', in which African writers must negotiate a 'coeval relationship' between written and spoken forms. ${ }^{20}$ In his reading, 'writers are representing societies in which oral-expressive practices are predominant and culturally rooted', but their texts are equally informed by an 'intertextual conversation' involving 'African as well as non-African writings and traditions.' ${ }^{21}$ This rich conception of the interface between written and oral forms is focalised by Quayson in his discussion of the role of orality in magical realism. He notes that 'most genres of orality retain a comfortable relationship to magical elements', and that these stand in contrast to 'Weberian notions of disenchantment that are supposed to

19 F. Abiola Irele, 'Orality, Literacy, and African Literature', in Tejumola Olaniyan and Ato Quayson (eds.), African Literature: An Anthology of Criticism and Theory (Oxford: Blackwell, 2007), pp. $74-82$.

20 Olakunle George, 'The Oral-Literate Interface', in Irele (ed.), The Cambridge Companion to the African Novel, pp. I 5-30; I 5, 28.

2 I Ibid., p. 28. 
have marked Western modernity'.22 He concludes with the observation that to read African magical realism is 'to engage with ... how [oral discourses] imbue, reshape, and ignite a sense of enchantment in a world that appears to be singularly disenchanted'. ${ }^{23}$ Quayson is careful throughout to qualify the extent to which Western modernity really is disenchanted: the world of modernity is only 'supposed' or 'appears' to be disenchanted. While the temptation might be to align orality with magic and the archaic and literacy with rationality, modernity, and disenchantment, this does not bear scrutiny. Irele's articulation of the contemporaneity of the oral defies any such representational time lag, George's concept of the 'orality-literacy dyad' disturbs any neat separation between written and oral forms and Quayson's careful analysis demands caution over the conceptual and representational 'illusionism' of realism. ${ }^{24}$

The co-presence of orality and realism in magical realist texts is, seen in one light, a relationship of juxtaposition in which the two emblematise conflicting worldviews and incongruous times. However, the mimetic component of realism - its goal to imitate or represent the world - brings with it both the uncanny effects of doubling and a performative, spell-like power to act on - or indeed make - the reality it supposedly imitates. In Mladen Dolar's words:

Is there, at the bottom of it [mimesis], a mechanism pertaining to magic? James G. Frazer has famously pinpointed two kinds of magic, the imitational one, which works by metaphors, by effigies, substitutes, similarity, analogy, at distance (what befalls the effigy will befall the original), and contact magic, which works by contiguity, metonymy, physical connection (contamination or healing by magic touch). ... In 'magical' thinking imitation has the power to contaminate the distant original, and on the other hand mere contact has the power to contaminate two contiguous entities. $^{25}$

The critical concern that mimesis has the power to alter the world it represents is here seen in a different light, namely as a form of magical thinking in which a textual effigy might effect distal magic on its model. Mimesis, in depicting the world, would then alter it in a form of graphic performative utterance or written hex that 'spells out' the reality it purports to imitate. The relation between orality and realism in magical realist texts

22 Quayson, 'Magical Realism and the African Novel', p. I6o. $\quad{ }^{23}$ Ibid., p. I75.

${ }^{24}$ J. M. Coetzee, Doubling the Point: Essays and Interviews, ed. by David Attwell (Cambridge, MA: Harvard University Press, I992), p. 27.

25 Mladen Dolar, 'The Comic Mimesis', Critical Inquiry, 43.2 (2017): 570-589; 58 I. 
is therefore not a representational figuring of premodern and modern worldviews, but rather is the recognition that these two modes are contemporaneous with one another, and that in both, words are able to act on the world, either proximally through speech or distally through writing.

To see how these intersecting vectors - the magical and the real, capitalism and its discontents, the oral and the written - have been used to disturb the assumptions of capitalist realism, Ngũgĩ offers a particularly interesting first example, as across his career he has made use of both realism and modes of writing that more explicitly incorporate orality, myth and magic. In his first three novels Weep Not, Child (1964), A Grain of Wheat (1967) and Petals of Blood (1977), he writes in English, in a largely realist mode. ${ }^{26}$ Then, in the late I970s, he switches from English to Gĩkũyũ for his novel Caitaani mũtharaba-Inĩ [Devil on the Cross] (1980/ I982), and in it, as well as in Wizard of the Crow, he develops a satirical form that occupies a space between orature and literature. Ngũgĩ discusses the shift in his style in an interview, in which he notes that while Weep Not, Child is written in 'what I might call the Victorian realism of the English novel', in more recent years, 'the novel, as a genre, [has been] changing with writers, particularly those from Africa, Asia and Latin America, finding inspiration from Orature, the oral and the aural inheritance of the peasantry'. ${ }^{27}$ Wizard of the Crow, he says, was particularly inspired and influenced by the trickster aesthetics of the oral narrative in Africa'. ${ }^{28}$ Indeed, the original three-part publication in Gĩkũyũ was designed to be read aloud and discussed publicly, rather than requiring the extended solitary quiet that typically characterises novel reading. The shift in Ngũgĩ's style becomes quickly apparent by comparing the openings of his earliest and most recent works. These are the opening three sentences of Weep Not, Child:

Nyokabi called him. She was a small, black woman, with a bold but grave face. One could tell by her small eyes full of life and warmth that she had once been beautiful. But time and bad conditions do not favour beauty. ${ }^{29}$

This looks and feels very much like realism, as present evidence can be used to make reasoned deductions about the past, the people that populate

\footnotetext{
${ }^{26}$ For a discussion of how orality influences even these novels, see George, 'The Oral-Literate Interface'.

27 Ngũgĩ wa Thiong'o, 'Interview with Ngũgĩ Wa Thiong'o', Aesthetica Magazine. Available at www.aestheticamagazine.com/ngugi-wa-thiongo. Accessed I 2 February 2019.

28 Ngũgĩ, 'Interview with Ngũgĩ Wa Thiong'o'.

29 Ngũgĩ wa Thiong'o, Weep Not, Child (London: Heinemann Educational, I964), p. 3.
} 
this world are subject to the inevitabilities of time and circumstance and the detailed description of this merciless process contributes to a way of being in and understanding that world that alters, in some small way, the world it describes. This is quite different from what we find in the opening three sentences of Wizard of the Crow:

There were many theories about the strange illness of the second Ruler of the Free Republic of Aburĩria, but the most frequent on people's lips were five.

The illness, so claimed the first, was born of anger that once welled up inside him; and he was so conscious of the danger it posed to his well-being that he tried all he could to rid himself of it by belching after every meal, sometimes counting from one to ten, and other times chanting ka ke ki ko $k u$ aloud. Why these particular syllables, nobody could tell. ${ }^{30}$

Here, the tone is closer to that of an oral tale, with the inverted syntax at the end of the first sentence giving a fable-like feel, and the affective aetiology of the Ruler's illness - not to mention the tendentiousness of his proposed cure - suggests a very different mode of perceiving, and so of being in, the world from that offered in his earlier novel.

Due to its unlikely characters and events, Wizard of the Crow has been described as a magical realist text, ${ }^{3 \mathrm{I}}$ and Ngũgĩ has responded to this in different ways. At times, he, like Mda and Okri, has expressed dissatisfaction with the term. As Simon Gikandi notes in his review of the novel:

Ngũgĩ has seemed irritated by suggestions that his work is an African version of the genre of 'magic realism' associated with Latin American writers of the 'boom' generation. He has reacted to such claims by reminding his interlocutors that his narrative models are drawn from Gîkũyũ folklore, not 'magic realism'. ${ }^{32}$

Gikandi does not point to any specific reviews, but if they do suggest that Ngũgĩ's work is a belated and derivative version of Latin American magical realism, then his irritation is understandable. However, in a recent interview, Ngũgĩ offers an alternative and perhaps more fruitful way to conceive of his work's relation to magical realism. He observes that the rediscovery of 'the magic of the oral tradition' by authors in Africa, Asia and Latin America has been a key component in the development of postcolonial

30 Ngũgĩ wa Thiong'o, Wizard of the Crow (London: Vintage, 2006), p. 3.

3I See, for example, Joseph McLaren, 'From the National to the Global: Satirical Magic Realism in Ngũgî's Wizard of the Crow', The Global South, 2.2 (2008): I 50-I 58.

32 Simon Gikandi, 'The Postcolonial Wizard: A Review of Ngũgĩ wa Thiong'o's Wizard of the Crow', Transition, 98.I (2008): I 56-I69; I60. 
literature, and that this reconnection has led to a 'magic realism' that has in turn influenced literature worldwide. ${ }^{33}$ In other words, for Ngũgĩ, magical realism can offer a useful heuristic for understanding the various projects of writers in very different locations who rediscover the alternative logics accessible through oral traditions. The globally distributed manifestations of magical realism together constitute a variegated and fissile conceptual space in which both oral and written forms have purchase on the world, and this space is able to make those who enter it see their world differently.

Wizard of the Crow is packed with oral forms, but these are not all presented on an equal footing. On the one hand, the main narrator, Arigaigai Gathere (who comes to be known as A.G., the Attorney General of storytelling), recounts the narrative of the book to the patrons of a bar, and there are oral performances scattered throughout the novel, as characters recount stories, improvise and embellish. The power of oral forms is, on the one hand, presented as a tool of contesting power, in accord with an understanding of magical realism in which the oral is coupled with indigeneity and the written with capitalist modernity. However, as Scott Esposito points out, orality in the novel is present not only in the text's narration, but also in the

techniques and the architecture used by political actors in Aburĩria as they continually invent tales that, with breathtaking speed, become the new realities that the country must live by. Whether it is the Ruler purposefully creating realities with an iron hand, businessman doing it in ignorance as they arrange deals, or even the resistance innocently slipping into stories that help them toward their goals, the creation of stories remains central. ${ }^{34}$

Oral forms can be used to contest power, but can also be the vehicle for the powerful to assert their dominance, as their words become fact. This kind of orality consists of speech acts - the Ruler's pronouncements, the agreements of businessmen - that are felicitous due to the structural position of those speaking. In this new world order, the very tools of orality can be used to buttress the operation of power, a representational equivalent to what Harry Garuba has termed 'retraditionalisation', in which indigenous practices are called upon to advance the interests of contemporary capital. ${ }^{35}$ Ngũgî's engagement with oral forms is therefore

${ }^{33}$ Ngũgĩ, 'Interview with Ngũgĩ wa Thiong'o'.

${ }^{34}$ Scott Esposito, 'Thrice Told Tales: How Stories Become Reality in Ngũgĩ wa Thiong'o's Wizard of the Crow', Quarterly Conversation. Available at http://quarterlyconversation.com/ngugi-wa-thiongowizard-of-the-crow. Accessed I 2 February 2019.

${ }^{35}$ Harry Garuba, 'Explorations in Animist Materialism: Notes on Reading/Writing African Literature, Culture, and Society', Public Culture, I 5.2 (2003): 26I-285; 264. 
not simply nostalgic, with the oral seen as a site of autochthonous purity and the written as a marker of postlapsarian decline. Rather, he recognises that the spoken word, like the written, can effect change, and this capacity can be used to both contest and consolidate power.

Ngũgĩ further complicates the role of orality by including passages of speech that are more akin to either realism or even technical, bureaucratic writing. Take, for example, the following speech by Tajirika, an advisor to the Ruler:

'... The Global Bank and the Global Ministry of Finance are clearly looking to privatize countries, nations, and states. They argue that the modern world was created by private capital. ... The world will no longer be composed of the outmoded twentieth-century divisions of East, West, and a directionless Third. The world will become one corporate globe divided into the incorporating and the incorporated. We should volunteer Aburĩria to be the first to be wholly managed by private capital, to become the first voluntary corporate colony, a corporony, the first in the new global order. With the privatization of Aburĩria, and with the NGOs relieving us of social services, the country becomes your real estate. ${ }^{36}$

This passage is delivered orally, but its analytical tone - save, perhaps, the punning 'incorporated' and 'corporony' - contrasts sharply with that of the dominant oral-style narration. Tajirika's argument for national privatisation is based on the pronouncements of the Global Bank and the Global Ministry of Finance, clear ciphers for the World Bank and the International Monetary Fund. The rationale is presented as logical and neutral: these organisations say that private capital made the modern world, therefore nations that are not run by private capital are backwards, therefore Aburiria should be privatised, with the social responsibilities of the state devolved to NGOs. However, this is pure sophistry. Private capital may have made the modern world, but its distortions have facilitated the reign of a dictator such as the Ruler and granted him the performative capacity to make his word become truth. Such tendentious first premises make a mockery of logical deduction, and so call into question the model of reality the Global Bank and the Global Ministry of Finance promote. As Gikandi rightly observes, Wizard of the Crow 'blurs the role between the folktale, as a privileged moral code, and the tall tale, postcolonial states' preferred mode of imagination'. ${ }^{37}$ Ngũgĩ's innovative rewiring of magical realism in this novel electrifies the orality-literacy dyad to show that the power of oral forms is not limited to their subversive potential and, further,

${ }^{36}$ Ngũgĩ, Wizard of the Crow, p. 746. $\quad{ }^{37}$ Gikandi, 'The Postcolonial Wizard', p. I6r. 
that what is passed off as reality - in fact, its thin and ascetic afterimage requires as much suspicion and scrutiny as the fantastical.

Where Ngũgĩ's novel shows how magical realism might mediate the grotesque distortions of global capital, Couto's shows how these concerns interleave with the aftermath of civil war. ${ }^{38}$ Sleepwalking Land narrates the horror of the civil war in Mozambique from the late I970s to the early I990s through the experiences of two refugees, a boy called Muidinga and his ageing companion Tuahir, as they make their way across a war-ravaged landscape. On their way, they find a burnt-out bus full of corpses and decide to make camp within it, to hide from a gang of violent thugs. They find among the remains the notebooks of one of the dead, a young man called Kindzu. Muidinga reads the notebooks to the illiterate older man, finding in them the story of Kindzu as he fled his war-torn village to become one of the naparama, 'traditional warriors, blessed by the witchdoctors against the war-mongers'. ${ }^{39}$ In a formal mediation of the oralityliteracy dyad, chapter by chapter, the book oscillates between Tuahir and Muidinga's conversations and Kindzu's story, which is accessed through the notebooks and realised as Muidinga reads them aloud to Tuahir.

There is no shortage of magical elements in the novel, in the form of Xipocos, 'ghosts that take joy from our suffering', and tchoti, 'dwarves that drop from the heavens, ${ }^{40}$ but also in characters such as Juney, a young boy who transforms into a chicken, and Skellington, a nightmarish old man strongly associated with oral culture through his performative storytelling, during which he shakes a rusty tin containing his self-extracted teeth, 'as if accompanying a song. ${ }^{4 \mathrm{I}}$ While orality is explored most explicitly through Skellington - his eventual death on encountering his written name reads, in effect, as a registration of graphocentric modernity's displacement of oral culture ${ }^{42}-$ the ghoulish operations of capital are most evident in the

${ }^{8}$ Sleepwalking Land, like Wizard of the Crow, exists across languages, being first published in Portuguese in 1992 and translated into English by David Brookshaw only in 2006. There is clearly much to say on the relationship between mimesis, doubling, temporal disjunction and translation, but limitations of space prevent any further exploration here.

39 Mia Couto, Sleepwalking Land, trans. by David Brookshaw (London: Serpent's Tail, 2006), p. 20.

40 Ibid., pp. 36, $56 . \quad{ }^{41}$ Ibid., p. 63.

${ }^{42}$ In an interview with Patrick Chabal, Couto recalls the association between old men, oral culture and magic when describing his youth in Mozambique: 'I keep from my childhood, such a very faint thing: a reference point, the stories that were told by the old men living near, by the old neighbours across the street who came from another world. And I remember this enchanted world of stories they left a mark on me'. Mia Couto and Patrick Chabal, 'Interview', in Vozes Moçambicanas (Lisbon: Vega, 1994), pp. 274-29I; 286, cited in 'Mia Couto or the Art of Storytelling', in Grant Hamilton, David Huddart and Patrick Chabal (eds.), A Companion to Mia Couto (Woodbridge: James Currey, 2016), pp. 86-105; 88. 
figure of Dom Romão Pinto, a white plantation owner who returns from the dead to pursue his economic interests. Romão, carrying his coffin on his back, appears to Estêvão Jonas, the black District Administrator, and the continuing influence of the former colonial power is immediately made clear. Romão commands Estêvão to

'Get up and help me carry this bloody coffin'.

Estêvão weighed up the situation, applied the most dialectical analysis in accordance with materialist teachings. Could he deal with a ghost? ${ }^{43}$

Couto here parodies the cognitive disjunction between the Marxist past of Frente de Libertação de Moçambique (FRELIMO) - it was MarxistLeninist from I 977 to 1990 - and the party's post-I 990 transition towards neoliberalism. At first, it seems that Estêvão's dialectical materialism is struggling to 'deal with' a ghost in the sense that a ghost's unstable ontology is incongruous with the realist worldview that subtends materialism. However, it emerges in their conversation that to 'deal with' a ghost is not just to assimilate its spectral presence into a rational system, but also to do business with it. Romão has come to strike a business deal with Estêvão, in which Romão provides the cash and Estêvão serves as the company's public face; due to the 'burden of race and nationality', as well as the inconvenience of his recent death, Romão 'would never be able to regain his former business interests'. If Estêvão can 'hurry things along with his signature and his duly native face fronting the enterprise, things would run as smoothly as saliva in a greedy mouth'. ${ }^{44}$ While for Marx the spectre haunting Europe was that of communism, here it is the avaricious ghost-in-the-'post-' of European colonialism that haunts 'administraitor' Estêvão, as the economic misconduct of the colonial past uncannily recurs in the neoliberal postcolonial present. ${ }^{45}$

Couto shares Ngũgî's concern for the faux-rationality of capitalist modernity and also that of orality's unstable political valency. In his novel, too, speech acts both bind communities in the aftermath of war - as is the case with Muidinga and Tuahir - and can distort reality in seeming instances of 'real talk'. This idea is focalised in Estêvão's meeting with Romão, as when Estêvão communicates his fears that the plan risks raising suspicion, Romão offers the following plan for how to deflect it:

43 Couto, Sleepwalking Land, p. I73. $\quad{ }^{44}$ Ibid., p. I74. $\quad{ }^{45}$ Ibid., p. I76. 
They agreed the necessary strategy: Estêvão Jonas should foster a policy of insult and onslaught and proclaim the privileges of the majority race.

'But by doing that, I'll damage you, Romão'.

'On the contrary, my dear partner'.

And he justifies his reasoning: in that way no one would suspect his pact with the white man. The Portuguese seemed to have given the matter a lot of thought during his stay away from existence. And he offered even more advice:

'Give a few speeches against the white scum. Just for the sake of appearance'.

As long as it wasn't over the top, it could even be funny. 'A regime gains legitimacy, my dear Estêvão, when there are no facts to back up arguments. ... ${ }^{46}$

In collaboration with Romão, Estêvão plans a series of public pronouncements decrying white economic and cultural privilege, while in fact profiting directly from its structural continuation. As with Ngũgĩ s dictator and his acolytes, for whom speech acts bring new economic realities into being, so for Estêvão, whose vociferous public disavowal of complicity - a 'policy of insult and onslaught' - establishes a counterfactual order. The more outrageously the regime's public self-representation diverges from what is actually happening, the less its claims are falsifiable by tangible proof: 'a regime gains legitimacy .... when there are no facts to back up arguments'. Although the conclusions of Romão's reasoning are paradoxical, his method is unflinchingly rational, with effects proceeding from causes in a manner that allows for strategy and future prediction. This is a world in which even a ghost can use reason to advance its economic interests, forcing us to think through the rationality of the world order that realism both reflects and produces.

As the analysis above shows, the conceptual rewiring performed by magical realist texts can, at its best, defamiliarise the naturalising logic of capitalist modernity and show us that there are alternative epistemological premises available. This rewiring short circuits any assumption that the parameters of one's own reality are necessarily shared by others, firstly by toppling the epistemological hierarchy between the natural and the supernatural and secondly by exposing the logical inconsistencies of colonial modernity's binary logics, which seek to distinguish the irrational from the rational and the magical from the real. As I discuss above, and as is amply evident in Ngũgĩ's and Couto's texts, the magical and the real are not only mutually constitutive, they can also share irrational procedures, and,

46 Ibid., p. I75. 
further, both texts instantiate the shared performative character of oral and written forms. Ngũgĩ uses a range of oral forms in Wizard of the Crow, not only to trouble the hierarchy between the written and the oral, but also to show how oral forms can be put to both resistant and oppressive uses. Similarly, Couto shows that while a traditional oral culture is waning, the spoken word - in Muidinga's reading aloud of Kindzu's notebooks, but also in Romão's and Estêvão's verbal smokescreening to hide business interests - continues to hold power. The decentring project of Ngũgĩ's and Couto's magical realism cuts both ways, neither accepting the totalising logics of capitalist modernity nor suggesting an idealised autochthonous alternative, neither ceding the terrain of the literary to the non-West nor attributing a putative authenticity to oral forms.

Reading the African novel in relation to magical realism, as I have done here, is not to suggest that African texts are belated or derivative attempts to emulate Latin American cultural production. African magical realist texts are often deeply informed by the oral forms that undergird the lifeworlds from which they emerge, and those oral forms are rewired firstly in the societal orality-literacy dyad and then once again as this dyad is mediated through literary works. The product of this encounter is not simply classifiable under a pre-existing rubric of magical realism, but rather constitutes a performative alteration of the parameters of magical realism as a discursive category, formed of both literary texts and their critical interpretations. African texts can certainly be read through the lens of magical realism, but only while recognising that to do so is to accept that magical realism will be changed forever. ${ }^{47}$

47 My thanks to Astrid van Aggelen, Emmanuele Santos, Kim Sasser and Christopher Warnes for their useful suggestions for this chapter. 